\title{
El Treball Educatiu a la Primera Infància. La Programació com a Millora de la Pràctica Professional
}

\author{
José Maria Cornadó Rebate ${ }^{a}$ \\ Data de defensa: 24/05/2013
}

Paraules clau: petita infància, llars d'infants, programació, infantil

\section{Justificació}

La tesi doctoral "El treball educatiu a la primera infància: la programació com a millora de la pràctica professional" analitza i reflexiona sobre "qui, com, quan i per a què" es planifica la tasca educativa al primer cicle de l'educació infantil.

Una de les tasques habituals de qualsevol educador i implícita, des del punt de vista professional, és programar, planificar, preparar i preveure allò que s'ha de fer amb els infants. La manera de fer-ho depèn de molts factors diferents entre els que destaquen, les orientacions de l'administració educativa, el projecte educatiu del centre, els acords de l'equip, la formació rebuda, les característiques i les conviccions personals entre d'altres.

Al llarg de la investigació s'analitza el que pensen i fan els professionals que hi treballen al primer cicle d'educació infantil, com planifiquen i porten a terme les activitats amb els infants, quins models utilitzen, quines dificultats es troben, que els aniria bé per realitzar amb més facilitat les seves programacions, en definitiva... es fa un estudi acurat de la situació actual.

Per finalitzar, es realitza una proposta concreta de treball per a que les llars d'infants puguin programar amb eines més flexibles i adaptades a les seves necessitats, i amb menys cost de temps per als professionals que hi treballen.

\footnotetext{
${ }^{a}$ Departament de Pedagogia. Universitat Rovira i Virgili - Tarragona
} 


\section{Conclusions}

La conclusió més significativa a que s'arriba en la investigació és que el primer cicle d'educació infantil no pot seguir l'estructura ni els models en la planificació del treball a l'aula que es fa en les altres etapes del sistema educatiu.

Les aules que acullen infants de 0 a 3 anys, tenen unes característiques molt específiques i els educadors necessiten de models més flexibles per programar. Les característiques evolutives dels infants en aquestes edats compliquen especialment les possibilitats per preveure i planificar les tasques didàctiques a realitzar.

Això no vol dir que no s'hagi de programar, sinó que cal models oberts i flexibles que possibilitin que la llar d'infants, cada curs escolar pugui adaptar allò que vol treballar al grup d'infants de cada aula.

Que l'administració educativa reconegui el caràcter educatiu dels centres que acullen la petita infància, no vol dir en absolut que l'organització dels centres i dels documents didàctics que s'utilitzen puguin seguir els mateixos paràmetres que els altres centres del sistema educatiu.

Acaba el treball amb una proposta sobre la programació a 0-3: Es donen pautes per a realitzar una programació anual i una unitat didàctica tenint en compte les prescripcions de l'administració educativa i l'escola, tot respectant la flexibilitat necessària. Es tracta d'un treball en quatres fases que va des de l'anàlisi dels eixos del currículum i les capacitats d'etapa acabant en la proposta d'activitats concretes per a infants. 